\title{
On The Importance Of Family In Family Firms
}

William B. Joyce, (E-mail: wbjoyce@eiu.edu), Eastern Illinois University

\begin{abstract}
Family values may play an important role in shaping the organization of businesses and their efficiency. This paper first addresses the question of "Why family firms?" Family firms are discussed from the perspectives long-term, substitution, human capital, and politics. The paper then addresses "family values and family firms" discussing nepotism, legacy, and inheritance norms.
\end{abstract}

\section{INTRODUCTION}

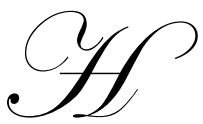

istory is replete with examples of spectacular ascents of family businesses. The Rothschilds, for example, not only amassed the greatest concentration of private wealth the Western world has ever seen, they are also credited with changing the fate of history by financing monarchs and kings: one of their most famous bets being the support for Wellington's armies, which ulti mately led to the defeat of Napoleon at Waterloo. At the height of their power, a French journalist reportedly said in 1841: "There is but one power in Europe and that is Rothschild" (Ferguson, 1998).

Yet there are also numerous accounts of family businesses brought down by bitter feuds among family members, disappointed expectations between generations, and tragic sagas of later generations unable to manage their wealth. One of the more spectacular examples in U.S. history is the Vanderbilt fortune. Cornelius Vanderbilt created a fortune in shipping and railroads. He is reported to have been as driven and ingenious as a businessman can be. However, only 50 years after his death, several of his direct descendants were penniless. John Kenneth Galbraith (as quoted in Vanderbilt, 1989), "said that several generations of Vanderbilts showed both the talent for acquiring money and the dispensing of it in unmatched volume, adding that they dispensed of their wealth for frequent and unparalleled self-gratification and very often did it with a forthright stupidity."

Examples of family businesses are not restricted to history textbooks. Even today a large fraction of businesses throughout the world are organized around families. The Murdochs at News Corporation, the Waltons at Walmart or the Rigas at Adelphia are just a few of the many current business dynasties whose fortunes and misfortunes the media has scrutinized closely. Family firms are characterized by a concentration of ownership, control and often key management positions among family members, even after the retirement of the firms' founders.

Such family arrangements are predominant among privately held firms, but are also present in a large fraction of publicly held firms. Involvement of families in businesses is very common in Latin America, Africa and the Middle East, and in parts of Western Europe and Asia: though there is a lot of heterogeneity across countries. For example, as reported by La Porta, Lopez-de-Silanes and Shleifer (1999), 65 percent of the 20 largest firms in Argentina have at least a 20 percent family stake; in Hong Kong this fraction is 70 percent. In contrast, in Japan, the fraction of family control among the 20 largest firms is only 5 percent. Even in the United States, families are not absent from large publicly traded firms. Anderson and Reeb (2003) show that some founding family ownership is present in 35 percent of firms in the Standard and Poor's 500 and represents about 18 percent of equity.

Why are family firms so prevalent? What are the implications of family control for the governance, financing and overall performance of these businesses? These questions are only beginning to receive attention in 
the economic research community. At the core of the debate is the question of whether family firms evolve as an efficient response to the institutional and market environments, or whether they are an outcome of cultural norms that might be costly for corporate decisions and economic outcomes.

The idea that a culture based on strong family ties may sometimes impede economic development is not new. Such a view dates back at least to Max Weber's 1904 essay, which argues that strong culturally predetermined family values may place restraints on the development of capitalist economic activities, which require a more individualistic form of entrepreneurship and the absence of nepotism. Another early proponent of this cultural view is Banfield (1958) who described the "amoral family" in the south of Italy as one of the main reasons for the smaller average firm size and slower economic development of the south relative to the north. He found in his work on families in southern Italy a potential trade-off between trust among the narrow realm of kinship networks and trust in the society at large. A similar argument has been developed by Fukuyama (1995), who puts forth that in societies where people are raised to trust their close family networks, they are also taught to distrust people outside the family, which impedes the development of formal institutions in society. Under such a cultural view, suboptimal economic organizations can emerge when parents put too much weight on keeping the business in the family, maybe due to a strong sense of duty towards other family members or a more selfish desire to turn the business into a family legacy.

\section{WHY FAMILY FIRMS?}

This section explores efficiency-based theories for family firms, under which family control is a source of comparative advantage for firms, allowing them to achieve superior economic outcomes over their non-family counterparts. In the following section, the cultural view is turned to, under which strong family values may inefficiently push business organizations towards family control.

\section{Managing For The Long Term}

The enormous longevity and success of some prominent family firms has prompted a popular perception that family-controlled firms embrace a longer-term approach to management. Widely-held corporations, in contrast, are often associated with short-term perspectives and myopia of corporate managers. In the words of Giovanni Agnelli, the late patriarch of the Italian industrial dynasty (as quoted in Betts, 2001): "The [family] company is an inheritance to be protected and handed on. It is the outcome of the next and each generation's commitment to the last." Similarly, John Walton of Wal-Mart describes his family's perspective on their involvement with Wal-Mart as follows (Weber and Lavel, 2001): "We view [the company] really more as a trust, as a legacy we are responsible for, rather than something we own." The underlying idea is that the links that binds current generations to future ones provide family firms with "patient capital," a focus on maximizing long-run returns and the desire to pursue investment opportunities that more myopic widely held firms would not.

The Rothschild family is a case of such dynastic thinking; the following discussion is based on Ferguson (1998). The family began its ascent with Mayer Amschel Rothschild and pioneered international finance during the industrialization of Europe in the eighteenth century. The Rothschilds made their fortune from exchange-rate transactions and bond-price speculation, and also developed the first international government bond market due to their close connections with governments throughout Europe. An essential part of Amschel Rothschild's strategy was to keep control of the business in family hands. The Rothschild coat of arms was a clenched fist with five arrows symbolizing the five sons, with the family motto beneath: "Concordia, Integritas, Industria" (Unity, Integ rity, Diligence). In his will, Amschel set the rules that would closely tie his family to the future of the business he had started. In particular, he dictated that all key positions in the House of Rothschild were to be held by male members of the family and that the family was to intermarry with their own first or second cousins. Such rules created a long-term commitment of the Rothschild family to the banking business. 


\section{Substitution}

An alternative explanation for the presence of family firms is that family ties serve as a second-best solution in countries with weak legal structures, since trust between family members can be a substitute for missing governance and contractual enforcement. In 1798, Amschel Rothschild sent one of his sons, Nathan, to England to establish an office from which Nathan would directly handle the firm's textile trade with England. Nathan took with him half of the firm's assets to set up operations (Bellow, 2003). Giving control to his trusted son likely gave Amschel much less to worry about than if he had selected an outside manager, who might have run away with the money. Ferguson (1998) demonstrates that these trust relationships were a key to the family business success, allowing the business to cover a wide geographical range at a time when law enforcement and communication across long distances were impossible. This enabled the Rothschilds to profit vastly from international business where they had almost no competition, and to weather political storms in different regions of their empire.

In a recent paper Burkart, Panunzi and Shleifer (2003) formalize the argument that family control may be a substitute for weak formal investor protection. If the pecuniary private benefits of control are large, a founder may decide it is best to retain a controlling ownership stake in the firm and to appoint a trusted family successor. This explanation for family-controlled businesses has been mainly applied to countries with weaker formal institutions, such as many in south Asia, where private benefits of control are expected to be largest. Note that family control in this case, while privately beneficial to the family, may be socially inefficient if this control is used to tunnel capital and resources away from minority shareholders.

\section{Human Capital}

Another often-heard argument for the superiority of family involvement is that it gives founders access to a better talent pool. This could be true if there is a strong within-family correlation in managerial talent. This could also be true if the transmission of knowledge about the business is easier between a founder and his lead to extensive "cooperation" between business and government. Morck, Strange-land and Yeung (2000) argue that, as a consequence, inefficient firms can survive and create implicit barriers to entry for more efficient and innovative new firms.

\section{Politics}

Finally, political connections can provide large benefits for private firms, especially in economies with high levels of corruption (Faccio, 2006). These connections may result in preferential access to public resources such as subsidized credit, government contracts or favorable legislation. Family firms might be especially wellpositioned to benefit from those transfers since they often have extensive kinship networks that stretch across politics and business. If trust relationships are strong among the family members, family firms might find it easier to maintain political connections or even build new ones by sending one or more of their children into politics.

This greater facility of family firms in dealing with the political system creates private benefits for the family, but can be socially inefficient if resources are channeled to connected but underperforming firms. In fact, Morck and Yeung (2004) argue that powerful business families can play an important role in sustain ing a high level of political corruption within an economy. If family firms indeed have longer horizons than their non -family counterparts as discussed above, those firms will be less likely to renege on their implicit contracts with politicians. Because of this long-term orientation, politicians might prefer to exchange "favors" with family firms. Therefore, the prevalence of strong family firms might endogenously lead to extensive "cooperation" between business and government. Morck, Strangeland and Yeung (2000) argue that, as a consequence, inefficient firms can survive and create implicit barriers to entry for more efficient and innovative new firms. 


\section{FAMILY VALUES AND FAMILY FIRMS}

In contrast to these efficiency explanations for family firms, cultural theories propose that the organization of business around families may not necessarily be an optimal adaptation to the economic environment but instead the outcome of a (partially) predetermined set of norms. Cultures that foster strong family ties may make it difficult for a founder to dissociate the family from the business, despite the possible costs this may impose on the business. If such cultural values shape the preferences of a founder, he might be willing to forgo financial returns in order to maximize his overall utility, which includes his respect of family values and obligations. (An alternative to modeling cultural norms as changes in the founders' utility function would be to assume that cultural norms impose exogenous constraints on a founder.) Therefore, family values can create efficiency distortions if they introduce non-monetary objectives into the founder's utility maximization that run counter to the optimal decisions for the business. By itself, a founder's desire to maximize the financial wellbeing of his family does not necessarily lead to any inefficiency for the business or the economy overall. A founder who wants to maximize the wealth he passes on to his children would be better off selling the business and distributing the cash flows among his children (or hiring a professional manager), if he sees that they are unable to run the business efficiently. It is therefore central to this cultural view that non-monetary factors enter into the founder's decision.

\section{Nepotism}

A culture based on strong family ties can give rise to nepotism. Barnett (1960), for example, analyzes Cantonese entrepreneurs who immigrated to the United States. He argues that they still use narrow kinship networks in making hiring decisions even after immigrating. This narrow "family focus," he suggests, ultimately impedes the ability of these firms to grow. More generally, because founders may derive utility from seeing relatives involved in the business, they may decide to hire key managers from within their kinship network rather than turn to more talented professional managers. Beyond the direct effect of these lower-quality appointments on performance, nepotism may also have adverse spillover effects in that it creates negative incentive effects throughout the organization. If lower-down employees know that promotion decisions are not tied to performance, they might be less willing to exert high effort or to remain within the family business, thus making it more difficult to retain talent.

One of the more egregious examples of nepotism is that of Suharto, the former dictator of Indonesia, and his youngest son, Tommy. Besides controlling political power in the country, Suharto was also involved in a number of private and state-owned companies in the economy. Tommy's dream was to turn Indonesia into an economic world power by developing a domestic automobile industry. Most industry observers at the time regarded Tommy's car project as a vanity-driven scheme that made no economic sense. But to allow his son to pursue this idea, the father installed him at the head of a new subsidiary in one of the family firms. He first tried to produce a domestic car, called the Timor. After this project failed, he convinced his father to buy him a majority stake in Maserati, the luxury car maker that produces Lamborghini, which led to similarly disastrous results (Singh and Loveard, 1996).

\section{Legacy}

Cultural beliefs might also dictate a will to build a family legacy, and instill the desire to ensure survival and family control at all cost. This objective may not always be aligned with the best long-run strategy, especially if it leads families to display excessive risk aversion or forgo profitable expansion strategies or mergers with other firms. Take the example of Tia, a company that was founded in 1933 by Carlos Steuer and had, by the early 1990s, become a very successful family retail business in Argentina. By the late 1990s, international pressures led Francisco de Narvaez, general manager of Tia and grandson of Carlos Steuer, to conclude that it might be best to sell the business. However, his mother, a large shareholder of Tia, immediately dismissed the prospect of selling the company, claiming: "I do not want to sell the company. It's part of my life. I've inherited it from my father, your grandfather. It's a sense of life for me, and I do not think I could live with the decision to sell" (Hill and Doughty, 2000). 
The Rothschilds' history also possibly illustrates the cost of wanting to build a family legacy. Just as close family control was a key to their nineteenth-century success, it contributed to their decline in the twentieth century. In 1901, with no male heir in sight, the Frankfurt House closed its doors after more than a century in business. For similar reasons the Rothschilds failed to establish a dominant presence in the United States before the turn of the century. This is often seen as the reason for their decline in the first half of the twentieth century (Ferguson, 1998).

\section{Inheritance Norms}

Finally, perhaps most symptomatic of the cultural constraints within family firms are the inheritance rules that govern many of these firms. Such inheritance norms vary from strict primogeniture, where the oldest son inherits everything, to equal sharing rules among all the sons of a founder. Rigid inheritance rules may have direct costs for family businesses. It has been argued, for instance, that the reliance on patrilinear relations by many Chinese businesses (likely a direct outcome of a Confucian belief system) is a driver of the small average size of these businesses (for example, Whyte, 1996). In addition, equal sharing rules that involve all of the sons of a founder in the business might breed conflict, since cooperation between siblings can be difficult to achieve, despite parental will. Even if strong ties originally exist between family members, daily interactions within the context of the family business may lead to brutal infighting. Indeed, there are many examples of families (and their businesses) ripped apart by such infighting. One extreme such case is that of the Thammawattana family in Thailand (Bangkok Post, 2003). Before the matriarch of the family died, she amended the business charter to stipulate that if any one of her children needed to sell his/her stake in the firm, the remaining children were the only ones who could buy these shares. In the years following her death, two of the heirs died from mysterious causes or inexplicable suicides. While none of the cases has been officially closed and no one has been convicted, the Thai press interprets these deaths as an outcome of intra-family rivalries.

In contrast, historians describe the emergence of male primogeniture in continental Europe during the thirteenth century as a consequence of intensified demographic transition. Goody, Thirsk and Thompson (1976) show that between the fifteenth and the eighteenth centuries the inheritance of land among large landowners and aristocracy was regulated by primogeniture, which ensured the stability of family wealth and thus enabled the families to benefit from scale economies in production. But primogeniture is not without problems either. It severely restricts the founders' ability to select the most talented person to take over the family firm. If the oldest son is not talented, primogeniture will endanger the survival of the entire business.

While such rigid inheritance rules may be constraining to family businesses, as discussed above, breaking away from these rules may also be costly if it destroys the expectations of individual family members about their place in the family and the business. Backman (2001), for example, describes the problems that plagued the Jumabhoy family, the richest Indian family in Singapore, when the patriarch decided in 1992 to pass o ver two of his sons and, instead, to give a large controlling stake in the group's holding company to one of his grandsons, whom he viewed as the most entrepreneurial member of the family. After six years of costly feuding between family members at the expense of the company's health (including secret acquisition deals and the like), the family eventually sold off what was left of the company in 1998.

\section{EVIDENCE}

How much systematic evidence is there for the economic superiority of family-controlled businesses? A reading of the empirical literature so far suggests: not a lot. Several papers have established that family firms appear to under-perform relative to non-family firms in most countries: for example, Claessens, Djankov, Fan and Lang (2002) for several southeast Asian countries; Morck, Strangeland and Yeung (2000) for Canada; and Cronqvist and Nilsson (2003) for Sweden. Two notable exceptions, though, are Khanna and Palepu (2000) who find that business groups in India, which are for the most part family-controlled, perform better than stand-alone firms in matched industries. There is also mixed evidence so far as to whether family-controlled firms are indeed a response to weak formal institutions (Holmen and Hogfeldt, 2004). Family-controlled businesses are far from absent in the United States even though there is limited scope for expropriation. Also, a country like Sweden is 
often used to exemplify a case where the estimated pecuniary private benefits of control are low (between 1 and 7 percent of market value) and yet the frequency of family-controlled firms high (Gilson, 2005). Moreover, Claessens, Djankov, Fan and Lang (2002) show that family firms under-perform relative to non-family firms, and even other group firms, in several Southeast Asian countries that score relatively low on the investor protection index.

Of course, one should be careful not to stretch any of the evidence too far, since these cross-sectional comparisons are subject to many possible omitted-variable and selection biases. Moreover, one might argue that the observed low performance of family firms is not inconsistent with high financial benefits for the families themselves. The low performance may reflect a tunneling of capital out of the firms by the controlling families. Thus, family firms may be worse for minority shareholders, but financially beneficial for families. In addition, family members may receive "favors" from politicians that are not reflected in their companies' balance sheets. A few recent papers have made some first steps in demonstrating the role that nepotism, family structure and inheritance norms may play in driving the performance of family businesses. Morck, Strangeland and Yeung (2000) show that the lower performance of family firms is in large part related to the passing of active management and control from the founder to his or her descendants.

\section{CONCLUSION}

Family values may play an important role in shaping the organization of businesses and their efficiency. However, the macro-type evidence presented here can at best be suggestive. More research needs to be done to assess the relevance of cultural explanations for family firms and the exact mechanisms through which family values affect firms. It would be of particular interest to understand which dimensions of family values are most persistent and have the biggest impact on family businesses. The empirical work in this paper has focused on the strength of family ties as one source of cultural differences across countries. Other family-related differences of interest would be variations in inheritance structures or marriage norms such as polygamy, which might affect the longevity and cohesion of family firms. The cultural view of family firms implies that these firms might be less willing to make changes to their overall strategy even when market pressures ask for such changes. Out of a sense of duty and respect for their elders, younger generations might find it difficult to change decisions such as where to locate, what to produce, or which customers to serve. Future work might develop empirical approaches to investigate such sources of differences between family firms and non-family firms.

Moreover, it will be important to understand the interaction between family values and the formal institutions within a country. If family values are indeed (partially) exogenous and do not simply adjust in response to the economic environment, a more complicated dynamic between family values and formal institutions will arise. For example, shocks to the market of corporate control or increased governance pressures could make it more costly to indulge in these family-centered preferences. Alternatively, better markets for corporate control could allow families to hire professional managers while maintaining the beneficial elements of family ownership. A very interesting example of such dynamics between formal and informal institutions is highlighted in the work by Greif (1989). He analyzes how kinship relationships and norms between Maghribi traders facilitate the enforcement of contracts across long distances. These norms gave the Maghribi traders a comparative advantage when they were forced to leave their original homestead around Baghdad and move to Northern Africa. However, Greif (1989) also shows that the inability to change these norms hurt them in the long run, since later on it prevented them from competing effectively with the Genoese traders, who were developing more advanced formal institutions.

Perhaps, much can be learned by taking seriously the "family" part of "family firms." The understanding of the nexus between family and firm should improve with more microeconomic studies that analyze how the structure of a given family (including its size, gender and age composition) alters the strategic choices and eventual performance of the family firm. Because of the very detailed data required to perform such analysis, future micro research on this work might be forced to proceed on a country by country basis. Ultimately, a richer understanding may be gained from the accumulation of many such detailed studies, spanning a wide range of countries with different cultural norms and formal institutions. 


\section{REFERENCES}

1. Anderson, R. and D. Reeb, 2003. Founding-Family Ownership and Firm Performance: Evidence from the S\&P 500, Journal of Finance, pp. 1301-28.

2. Backman, M. 2001. Asian Eclipse: Exposing the Dark Side of Business in Asia. Singapore: John Wiley \& Sons.

3. $\quad$ Banfield, E., 1958. The Moral Basis of a Backward Society. New York: Free Press.

4. Barnett, M., 1960. Kinship as a Factor Affecting Cantonese Economic Adaptation in the United States, Human Organization, pp. 40-46.

5. Bellow, A., 2003. In Praise of Nepotism: A History of Family Enterprise from King David to George W. Bush. New York: Anchor Books.

6. $\quad$ Betts, P., 2001. Family Companies Are Ready for the Worst, Financial Times, October 3.

7. Burkart, M., F. Panunzi, and A. Shleifer, 2003. Family Firms, Journal of Finance, pp. 2167-202.

8. Claessens, S., S. Djankov, J. Fan, and L. Lang, 2002. Disentangling the Incentive and Entrenchment Effects of Large Shareholdings, Journal of Finance, pp. 2741-71.

9. Cronqvist, H. and M. Nilsson, 2003. Agency Costs of Controlling Minority Shareholder, Journal of Financial and Quantitative Analysis, pp. 695-719.

10. Ferguson, N., 1998. The House of Rothschild: Money's Prophets, 1798 -1848. New York, NY: Penguin.

11. Fisman, R., 2001. Estimating the Value of Political Connections, American Economic Review, pp. 10951102.

12. Fulcyama, F., 1995. Trust: The Social Virtues and the Creation of Prosperity. New York: Free Press.

13. Gilson, R., 2005. Controlling Shareholders and Corporate Governance: Complicating the Comparative Taxonomy, Stanford Law and-Economics Olin Working Paper No. 309.

14. Goody, J., J. Thirsk, and E. Thompson, eds, 1976. Family and Inheritance: Rural Society in Western Europe, 12001800. Cambridge: Cambridge University Press.

15. Greif, A., 1989. Reputation and Coalitions in Medieval Trade: Evidence on the Maghribi Traders, Journal of Economic History, pp. 857-82.

16. Hill, L. and K. Doughty, 2000. Francisco de Narvaez at Tia: Selling the Family Business, Harvard Business Case 9-401-017.

17. Holmen, M. and H. Peter, 2004. A Law and Finance Analysis of Initial Public Offerings, Journal of Financial Intermediation, pp. 324-58.

18. Khanna, T. and K. Palepu, 2000. Is Group Affiliation Profitable in Emerging Markets? An Analysis of Diversified Indian Business Groups, Journal of Finance, pp. 867-91.

19. La Porta, R., F. Lopez-De-Silanes, and A. Shleifer, 1999. Corporate Ownership around the World, Journal of Finance, pp. 471-518.

20. Morck, R. and B. Yeung, 2004. Family Control and the Rent-Seeking Society, Entrepreneurship: Theory and Practice, pp. 391-409.

21. Morck, R., D. Stangeland, and B. Yeung, 2000. Inherited Wealth, Corporate Control, and Economic Growth? in Concentrated Corporate Ownership. R. Morck, ed., NBER Conference Volume. Chicago: University of Chicago Press.

22. Vanderbilt, T., 1989. Fortune's Children: The Fall of the House of Vanderbilt. New York: William Morrow.

23. Weber, J. and L. Lavelle, 2003. Family, Inc., Business Week. November 10.

24. Weber, M., 1904. The Protestant Ethic and the Spirit of Capitalism. New York: Scribner's Press.

25. Whyte, M., 1996. The Chinese Family and Economic Development: Obstacle or Engine? Economic Development and Cultural Change, pp. 1-30. 
International Business \& Economics Research Journal - April 2007

Volume 6, Number 4

NOTES 